\title{
Evaluasi Kesiapan Dan Penerimaan Pengguna Sistem Informasi Management Tugas Akhir (SIMTEKNIK) Menggunakan Metode TRAM (Technology Readiness Acceptance Model)
}

\author{
Lailatul Hasanah ${ }^{* 1}$, Evi Dwi Wahyuni ${ }^{2}$, Wildan Suharso ${ }^{3}$ \\ 1,2,3Teknik Informatika/Universitas Muhammadiyah Malang \\ lailatulh26@gmail.com¹, evi.d.wahyuni@gmail.com², wsuharso@gmail.com³
}

\begin{abstract}
Abstrak
SIMTEKNIK merupakan sistem informasi yang dipakai oleh mahasiswa Fakultas Teknik universitas Muhammadiyah malang di mana biasanya pada digunakan untuk kegiatan terkait tuntutan tugas akhir atau skripsi. SIMTEKNIK sendiri merupakan sistem informasi baru yang digunakan sehingga di mana ditemukan beberapa permasalahan terkait sistem seperti interface yang ada belum cukup friendly, serta kurang nyaman terhadap tampilan tulisan warna hingga desain sistem, kesulitan mencari beberapa menu ketika pertama kali digunakan hingga waktu tunggu saat upload file termasuk lama. Berdasarkan permasalahan-permasalahan tersebut, maka perlu dilakukan sebuah analisis untuk mengetahui bagaiman penerimaan dan kesiapan pengguna terhadap SIMTEKNIK. Analisi kesiapan dan penerimaan pengguna perlu dilakukan karena langkah pertama yang harus dilakukan dalam implementasi teknologi adalah mengetahui kesiapan pengguna dalam menerima teknologi tersebut. adapun Model yang digunakan dalam penelitian ini adalah metode TRAM (Technology Readiness Acceptance Model) Metode TRAM adalah gabungan dari Technology Readiness Index dan Technology Acceptance Model yang pertama kali dikemukakan oleh Lin dkk tahun 2005. Hasilnya ditemukan bahwa dari 9 hipotesi terdapat 5 hipotesisi yang diterima dan 4 lainnya ditolak. hipotesis yang diterima yakni, OPT$>P E U, I N N->P E U, D I S->P U, D I S->P E U$ dan PEU->PU
\end{abstract}

Kata Kunci: SIMTEKNIK, Kesiapan dan P enerimaan, TRAM

\begin{abstract}
SIMTEKNIK is an information system used by students of the Faculty of Engineering of the poor university of Muhammadiyah University which is usually used for activities related to the demands of the final project or thesis. SIMTEKNIK itself is a new information system that is used so that where there are found a number of system-related problems such as interface the existingthat is not yetenough friendly, and is less comfortable with the display of color writing to the system design, difficulty finding multiple menus when first used up to the waiting time when uploading files including long. Based on these problems, it is necessary to do an analysis to find out how user acceptance and readiness of SIMTEKNIK. Analysis of user readiness and acceptance needs to be done because the first step that must be done in implementing technology is knowing the user's readiness in accepting the technology. As for the model used in this study is the TRAM method (Technology Readiness Acceptance Model) The TRAM method is a combination of the Technology Readiness Index and the Technology Acceptance Model that was first proposed by Lin et al in 2005. The results found that from 9 hypotheses there were 5 hypotheses that were accepted and 4 others were rejected. accepted hypothesis namely, OPT-> PEU, INN-> PEU, DIS-> PU, DIS-> PEU and PEU-> PU.
\end{abstract}

Keywords: SIMTEKNIK, Readiness and Acceptance, TRAM

\section{Pendahuluan}

Penerapan teknologi informasi ini merupakan aspek utama untuk lebih maju bagi satu instansi atau perusahaan. Perusahaan atau instansi dapat membangun Sistem infomasi manajemen yang handal dan berpengaruh secara signifikan terhadap kinerja organisasi, perusahaan atau institusi secara keseluruhan dalam mendukung upaya menciptakan sistem organisasi, perusahaan atau institusi yang terkendali, efisien dan kompetitif [1]. 
Salah satu lembaga yang juga menerapkan kemajuan Sistem informasi berupa website sebagai penyedia informasi yang lebih cepat dan effisien adalah Universitas Muhammadiyah Malang (UMM). Sebagai salah satu lembaga pendidikan tinggi yang selalu mengikuti perkembangan teknologi informasi dan memanfaatkan teknologi dengan baik, UMM berusaha memberikan berbagai fasilitas pelayanan kepada seluruh civitas akademika UMM yaitu dengan cara menyediakan berbagai Sistem informasi akademik yang memanfaatkan teknologi intemet salah satunya Sistem Informasi Management Tugas Akhir (SIMTEKNIK).

Sistem informasi Management Tugas Akhir (SIMTEKNIK) merupakan sebuah sistem yang menyediakan pelayanan informasi dan data terkait tugas akhir mahasiswa teknik infomatika UMM. Sistem ini mampu mempermudah setiap mahasiswa ketika akan melakukan tugas akhir tanpa harus berkali kali mendatangi kantor jurusan, baik itu pendaftan, cek kuota dosen, hingga penerbitan SK, sehingga waktu yang dikeluarkan menjadi lebih efisien. Sistem informasi Management tugas akhir sendiri merupakan sistem generasi pertama dan di golongkan sebagai sistem informasi baru yang di perlukan adanya evaluasi terkait Sistem, salah satunya dari segi kesiapan dan penerimaan pengguna terhadap Sistem.

Berdasarkan survey pendahuluan yang telah dilakukan pada sepuluh mahasiswa tingkat akhir diketahui terdapat beberapa permasalahan, user berpendapat tigkat kemudahan login sudah bisa dikuasai namun interface yang ada belum cukup friendly, serta kurang nyaman terhadap tampilan tulisan dan warna dan desain sistem yang terlalu kaku, kesulitan mencari beberapa letak menu seperti log out dll, serta waktu tunggu penguploadtan file sedikit lama. Dari berbagai permasalahan di atas maka diperlukan sebuah evaluasi untuk mengetahui bagaimana kesiapan dan penerimaan user terhadap Sistem Informasi Management Tugas Akhir (SIMTEKNIK) karena Sistem Informasi Management Tugas Akhir (SIMTEKNIK) yang wajib digunakan oleh setiap mahasiswa Informatika UMM untuk menyelesaikan kelengkapan administrasi terkait tugas akhir.

Pengevaluasian Sistem informasi Management Tugas Akhir (SIMTEKNIK) dilakukan bukan hanya karena sistem yang masih baru namun kesiapan pengguna terhadap sistem juga sangat penting. Kesiapan terhadap teknologi infomasi juga mempengaruhi kemajuan pola pikir individu, artinya semakin individu siap menerima teknologi yang baru berarti semakin maju pemikiran individu tersebut yaitu bisa beradaptasi dengan teknologi yang semakin lama semakin berkembang ini (Desmayanti, 2012) [2]. Penerimaa pengguna juga tidak kalah penting penerapannya Dalam sistem informasi penerimaan pengguna merupakan Salah satu unsur penting dalam Penerapan sebuah sistem informasi. Kesuksesan sebuah sistem infomasi tidak hanya Ditentukan oleh bagaimana sistem dapat memproses masukan dan menghasilkan informasi Dengan baik, tetapi juga bagaimana pengguna mau menerima dan menggunakannya, Sehingga mampu mencapai tujuan organisasi (Arif Surachman, 2008) [3].

Salah Satu metode yang bisa digunakan untuk melakukan evaluasi dalam penelitian ini adalah TRAM atau Technology Readiness and Acceptance Model. Metode TRAM (Technology Readiness and Acceptance Model) merupakan sebuah pebaharuan model baru yang menggabungan dimensi kepribadian dari Technology Readiness Index (TRI) dengan pengukuran kemanfaatan dan kemudahan penggunaan Technology Acceptance Model (TAM). Sehingga TRAM menjelaskan bagaimana dimensi kepribadian dapat mempengaruhi cara orang berinteraksi dengan teknologi dan penggunaannya [4]. Dalam model TRAM yang di usulkan Lin et al (2007) terdapat enam variabel yaitu (a) optimism (optimis), (b) innovationness (inovatif), (c) insecurity (ketidakamanan), (d) discomfort (ketidaknyamanan), (e) perceive usefulness (kemanfaatan), (f) perceive of use (kemudahan).

Pada penelitian yang dilakukan oleh Luqman Isyraqi, yang berjudul "Pengaruh Kesiapan Penerimaan Pengguna Terhadap Penerapan Sistem Informasi di Antara Lembaga Keuangan Mikro Syaria" Peneliti melakukan analis untuk mengetahui pengaruh kesiapan dan penerimaan pengguna terhadap Sistem Informasi LKMS dengan menggunakan model TRAM sebagai metode penelitian. Hasil akhir dari penelitian ini adalah menjabarkan hasil dari 10 hipotesa yang ada yakni 3 dari 7 hipotesa ditolak. Di mana faktor yang mempengaruhi adalah perbedaan objek, sampel dan instrument pada penelitian. Dan dapat dilihat bahwa dalam lingkup LKMS terdapat beberapa pengaruh yang terjadi antara kesiapan [5]. Sedangkan pada penelitian yang dilakukan oleh Riky Noprianto, yang berjudul "Studi Literatur Pengintegrasian Dua Metode Kesiapan Dan Penerimaan Pengguna Terhadap Teknologi Infonnasi Dan Komunikasi". Di mana pada penelitian ini lebih fokus kepada penerapan penerapan metode TRAM. Hasil akhir dalam penelitian ini adalah variable optimis pengguna berpengaruh posistif dan signifikasi terhadap presepsi kemanfaatan

REPOSITOR, Vol. 2, No. 7, Juli 2020: 985-996 
dan kemudahan. Sedangkan pada variebel innovatif pengguna berpengauh secara positif dan signifikasi terhadap kemanfaatan namun pada presepsi kemudahan tidak signifikasi. Ketidaknyamanan pengguna berpengaruh negative dan signifikasi terhadap presepsi kemanfaatan namun terhadap kemudahan pengguna.

Faktor ketidaknyamanan tidak berpengaruh pada kemanfaatan. Sedangkan faktor kemudahan pengguna berpengaruh positif dan signifikan terhadap kemanfaatan.

Berbeda dengan beberapa penelitian di atas pada penelitian ini sama-sama menerapkan metode TRAM dalam sistem informasi namun studi kasus yang dipakai dalam penelitian sangatlah berbeda. Pada penelitian ini menggunakan Sistem Informasi Management Tugas Akhir (SIMTEKNIK) di mana SIMTEKNIK sendiri merupakan sistem baru yang digunakan oleh mahasiswa tingkat akhir Informatika UMM. Penelitian kesiapan dan penerimaan user pada sistem belum pernah dilakukan evaluasi sebelumnya oleh karena itu peneliti ingin melakukan evaluasi dengan menerapkan metode TRAM untuk mengetahui kesiapan dan penerimaan user SIMTEKNIK.

\section{Metodologi}

Pada Gambar 1, metode yang dipakai dalam penelitian ini adalah metode TRAM (Technology Readiness Acceptance Model). TRAM sendiri merupakan sebuah kontribusi metode baru yang menggabungkan kesamaan dari TRI secara positif dengan sebuah presepsi dimensi bagi kegunaan sebuah teknologi kepribadian dengan dimensi spesifik atau disebut dengan TAM.

Dalam hal ini akan menjabarkan tentang bagaimana sebuah dimensi kepribadian akan mempengaruhi beberapa aspek pengalaman seseorang serta bagaimana cara dia menggunakan teknologi baru TRI dimensi kepribadian adalah anteseden TAM.

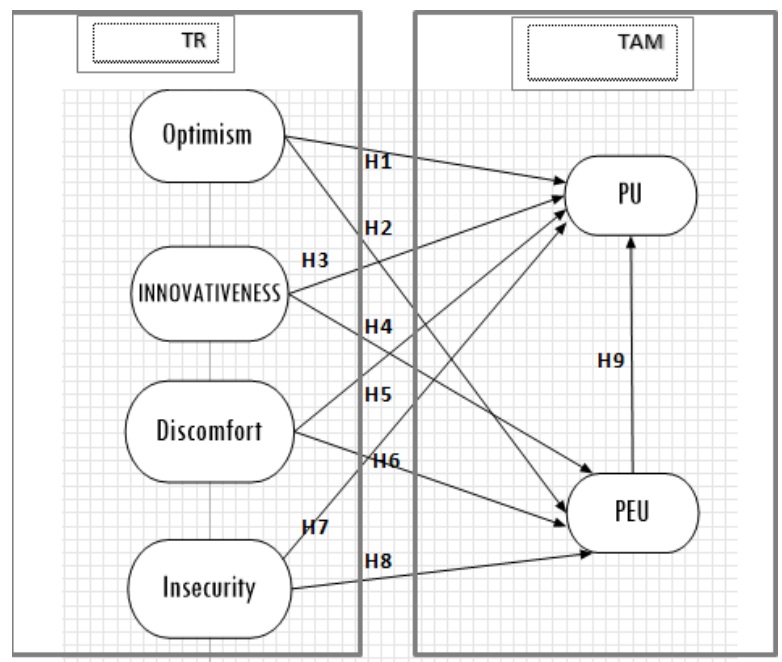

Gambar 1. Metode TRAM

Adapun hipotesa dengan menggunakan metode TRAM yang terdapat pada penelitian ini adalah:

\section{a. H1 Optimism terhadap PEU}

$\mathrm{H} 1$ : optimism berpengaruh secara positif pada persepsi kemudahan (PEU).

$\mathrm{HO}$ : optimism tidak berpengaruh secara signifikan positif pada persepsi kemudahan pengguna (PEU).

\section{b. H2 Optimism terhadap PU}

$\mathrm{H} 1$ : optimism berpengaruh secara positif pada persepsi kemanfaatan pengguna $(P U)$. $\mathrm{H} 0$ : optimism tidak berpengaruh secara positif pada persepsi kemanfaatan (PU).

\section{c. H3 Innovativness terhadap PEU}

$\mathrm{H} 1$ : innovativness berpengaruh secara positif pada persepsi kemudahan (PEU).

$\mathrm{HO}$ : innovativness tidak berpengaruh secara positif pada persepsi kemudahan (PEU). 
d. H4 Innovativness terhadap PU

$\mathrm{H} 1$ : innovativness berpengaruh secara positif pada persepsi kemanfaatan (PU).

HO: innovativness tidak berpengaruh secara positif pada persepsi kemanfaatan (PU).

\section{e. H5 Disscomfort terhadap PEU}

$\mathrm{H} 1$ : disscomfort berpengaruh secara negatif pada persepsi kemudahan (PEU). H0: discomfort tidak berpengaruh secara signifikan negatif pada persepsi kemudahan (PEU).

\section{f. H6 Disscomfort terhadap PU}

$\mathrm{H} 1$ : disscomfort berpengaruh secara negatif pada persepsi kemanfaatan (PU).

$\mathrm{HO}$ : disscomfort pengguna tidak berpengaruh secara negatif pada persepsi kemanfaatan (PU).

\section{g. H7 Insecurity terhadap PEU}

$\mathrm{H} 1$ : insecurity pengguna berpengaruh secara signifikan negatif pada persepsi kemudahan (PEU).

$\mathrm{HO}$ : insecurity pengguna tidak berpengaruh secara signifikan negatif pada persepsi kemudahan (PEU).

\section{h. H8 Insecurity terhadap PU}

$\mathrm{H} 1$ : insecurity pengguna berpengaruh secara signifikan negatif pada persepsi kemanfaatan $(P U)$.

$\mathrm{HO}$ : insecurity pengguna tidak berpengaruh secara signifikan negatif pada persepsi kemanfaatan $(P U)$.

\section{i. H9 PEU terhadap PU}

H1: Persepsi kemudahan ( $P E U$ ) pengguna berpengaruh secara positif pada Persepsi kemanfaatan $(P U)$.

H0: Persepsi kemudahan (PEU) pengguna berpengaruh secara positif pada Persepsi kemanfaatan $(P U)$.

\section{Analisa Hasil Penelitian}

Dalam penelitian ini data diperoleh dari hasil penyebaran kuesioner yang dilakukan pada Responden. Adapun responden pada penelitian ini adalah seluruh mahasiswa tingkat akhir fakultas teknik UMM yang sedang melakukan tugas akhir. Penyebaran kuesioner dilakukan dengan cara membagikan kuesioner kepada responden secara langsung serta peneliti memberikan tanggapan jika responden memiliki pertanyaan terkait pertanyaan-pertanyaan yang kurang di pahami, serta menggunakan 100 responden diambil sebagai sampel dalam penelitian.

Dalam pemrosesan data dianalisis menggunakan metode Partial Least Structural Equation Modelling (PLS-SEM). PLS-SEM merupakan model SEM yang lebih memfokuskan pada model prediksi, sehingga tidak perlu adanya dukungan teori yang kuat. Pada penelitian ini PLS-SEM dipakai untuk tujuan memprediksi apakah sebuah hubungan dan proposisi untuk pengujian atau tidak. Tujuan utamanya adalah menjelaskan hubungan antar konstruk dan menekankan pengertian tentang nilai hubungan tersebut. Hal penting yang harus diperhatikan adalah adanya teori yang memberikan asumsi untuk menggambarkan model, pemilihan variabel, pendekatan analisis, dan interpretasi hasil [6]. Tak hanya itu PLS juga bisa dipakai untuk tujuan pembukatian atau sebuah konfirmasi seperrti sebuah pengujian hipotesis dan tujuan untuk eksplorasi [7].

Dalam PLS-SEM sendiri biasanya terdiri dari dua jenis model pengukuran yakni, model pengukuran (measurement model) atau sering disebut outer model dan model struktural (structural model) atau disebut inner model. Pada outer model memiliki tujuan untuk menunjukkan bagaimana sebuah variabel manifest atau observed variable merepresentasikan variabel laten untuk di ukur, sedangkan model struktural menunjukkan kekuatan estimasi antar variabel laten atau konstruk [6]. Dan pada penelitian ini penggunaan PLS-SEM untuk mengukur nilai kesiapan dan penerimaan pengguna serta memprediksi hubungan dari kesiapan dan penerimaan terhadap penggunaan SIMTEKNIK.

\subsection{Outer Model (measurement model)}

Outer model merupakan sebuah metode bagaimana setiap blok pada indikator saling berhubungan dengan variabel latennya. Fungsi penggunaan outer model untuk menguji tingkat

REPOSITOR, Vol. 2, No. 7, Juli 2020: 985-996 
validitas konstruk dan reliabilitas instrumentnya di mana biasanya baik tidaknya sebuah instrumen pada penelitian ditentukan oleh validitas dan reliabilitasnya. Di mana Instrumen dikatakan valid saat bisa mengungkap data dari variabel secara tepat tidak menyimpang dari keadaan yang sebenarnya. Instrumen dikatakan reliabel saat dapat mengungkapkan data yang dapat dipercaya (Arikunto, 2010). Adapun kriteria pengujian validitas diuji dengan cara menggunakan convergent validity dan discriminan validity sedangkan pada kriteria pengujian reliabilitas diuji menggunakan average variance extraced dan construck reliability. Penjelasan dari 4 pengujian diatas adalah sebagai berikut:

\section{Validitas Konvergent (convergent Validity)}

Pada tahap uji validitas yang pertama ini adalah uji Validitas Konvergen atau convergent Validity, di mana pengujian ini dilakukan untuk mengukur besarnya korelasi antara konstrak dengan variabel latennya serta untuk mengetahui valid tidaknya sebuah data yang diolah menggunakan software SMARTPLS, dengan mencari nilai validitas konvergen sama dengan outer loading atau loading vactor. Nilai Loading Factor dianggap ideal apabila bernilai 0,7 dan dikatakan cukup apabila nilai berkisar antara 0,5-0,6. Berdasarkan hasil perhitungan pada Tabel 1 ditemukan bahwa nilai dari indikator OPT7, INN1, INS8, DIS1, DIS3, DIS4, DIS5, DIS6, DIS8 memiliki nilai loading factor kurang dari 0.5 . oleh karena itu kedelapan model tersebut harus dihapus dari model [7].

Tabel 1. Hasil Uji Validitas Konvergen

\begin{tabular}{|c|c|c|c|}
\hline Variabel & Indikator & Nilai LF & Keterangan \\
\hline \multirow{9}{*}{ Optimism } & OPT1 & 0.72 & Valid \\
\hline & OPT2 & 0.70 & Valid \\
\hline & OPT3 & 0.63 & Valid \\
\hline & OPT4 & 0.79 & Valid \\
\hline & OPT5 & 0.64 & Valid \\
\hline & OPT6 & 0.77 & Valid \\
\hline & OPT8 & 0.76 & Valid \\
\hline & OPT9 & 0.59 & Valid \\
\hline & OPT10 & 0.79 & Valid \\
\hline \multirow{6}{*}{ Innovativeness } & INN2 & 0.72 & Valid \\
\hline & INN3 & 0.88 & Valid \\
\hline & INN4 & 0.51 & Valid \\
\hline & INN5 & 0.69 & Valid \\
\hline & INN6 & 0.88 & Valid \\
\hline & INN7 & 0.53 & Valid \\
\hline \multirow{8}{*}{ Insecurity } & INS1 & 0.70 & Valid \\
\hline & INS2 & 0.72 & Valid \\
\hline & INS3 & 0.80 & Valid \\
\hline & INS4 & 0.65 & Valid \\
\hline & INS5 & 0.71 & Valid \\
\hline & INS6 & 0.70 & Valid \\
\hline & INS7 & 0.66 & Valid \\
\hline & INS9 & 0.72 & Valid \\
\hline \multirow{5}{*}{ Discomfort } & DIS2 & 0.72 & Valid \\
\hline & DIS6 & 0.68 & Valid \\
\hline & DIS7 & 0.70 & Valid \\
\hline & DIS9 & 0.67 & Valid \\
\hline & DIS10 & 0.78 & Valid \\
\hline \multirow{6}{*}{$\begin{array}{l}\text { Perceive } \\
\text { Usefulness }\end{array}$} & USE1 & 0.65 & Valid \\
\hline & USE2 & 0.78 & Valid \\
\hline & USE3 & 0.87 & Valid \\
\hline & USE4 & 0.84 & Valid \\
\hline & USE5 & 0.85 & Valid \\
\hline & USE6 & 0.76 & Valid \\
\hline
\end{tabular}




\begin{tabular}{cccc}
\hline & EASE1 & 0.80 & Valid \\
\cline { 2 - 4 } ceive Ease of Use & EASE2 & 0.77 & Valid \\
\cline { 2 - 4 } & EASE3 & 0.75 & Valid \\
\cline { 2 - 4 } & EASE4 & 0.61 & Valid \\
\cline { 2 - 4 } & EASE5 & 0.70 & Valid \\
\cline { 2 - 4 } & EASE6 & 0.76 & Valid \\
\hline
\end{tabular}

\section{Validitas Diskriminan (Discriminan Validity)}

Dalam pengujian validitas selanjutnya adalah uji diskriminan seperti pada Tabel 2, pengujian ini dilakukan untuk mengecek ke valid tidaknya tiap variabel serta untuk menguji dan mengukur sebuah konstruknya juga, uji ini dilakukan dengan cara melihat nilai cross loading dengan cara membandingkan nilai cross loading indikator dengan variabelnya dengan variabel lainnya. Bila nilai cross loading indikator dengan indikatornya lebih tinggi daripada dengan variabel lainnya, maka hal ini menunjukkan konstruk tersebut memprediksi ukuran blok variabel tersebut lebih tinggi daripada ukuran blok lainnya (Ghozali, 2008) [7]. Artinya nilai cross loading pada pada konstruk asosiasinya haruslah lebih besar dari pada nilai pada konstruk lainnya sehingga hasilnya dapat dikatakan valid dan dilanjutkan pada tahap berikutnya, sedangkan hasil semua pengujian dinyatakan valid.

Tabel 2. Hasil Uji Validitas Diskriminan

\begin{tabular}{|c|c|c|c|c|c|c|c|c|}
\hline \multirow{2}{*}{ VAR } & \multirow{2}{*}{ IND } & \multicolumn{6}{|c|}{$\mathrm{CL}$} & \multirow{2}{*}{ Keterangan } \\
\hline & & OPT & INN & INS & DIS & PU & PEU & \\
\hline \multirow{9}{*}{ OPT } & OPT1 & 0.71 & 0.09 & -0.26 & 0.12 & 0.32 & 0.21 & Valid \\
\hline & OPT2 & 0.70 & 0.06 & -0.08 & 0.03 & 0.19 & 0.10 & Valid \\
\hline & OPT3 & 0.63 & 0.11 & -0.19 & 0.32 & 0.18 & 0.18 & Valid \\
\hline & OPT4 & 0.79 & 0.06 & -0.10 & 0.17 & 0.27 & 0.22 & Valid \\
\hline & OPT5 & 0.64 & 0.15 & -0.09 & 0.02 & 0.11 & 012 & Valid \\
\hline & OPT6 & 0.77 & 0.10 & -0.12 & 0.13 & 0.34 & 0.31 & Valid \\
\hline & OPT8 & 0.76 & 0.10 & -0.19 & 0.26 & 0.25 & 0.20 & Valid \\
\hline & OPT9 & 0.59 & 0.5 & -0.12 & 0.30 & 0.26 & 0.27 & Valid \\
\hline & OPT10 & 0.79 & 0.0 .6 & -0.08 & 0.18 & 0.22 & 0.24 & Valid \\
\hline \multirow{6}{*}{ INN } & INN2 & 0.26 & 0.72 & 0.08 & 0.04 & 0.16 & 0.22 & Valid \\
\hline & INN3 & 0.01 & 0.88 & -0.16 & 0.20 & 0.26 & 0.46 & Valid \\
\hline & INN4 & 0.12 & 0.51 & 0.05 & 0.00 & 0.08 & 0.24 & Valid \\
\hline & INN5 & 0.26 & 0.69 & -0.08 & -0.01 & 0.18 & 0.21 & Valid \\
\hline & INN6 & -0.00 & 0.88 & -0.04 & 0.15 & 0.32 & 0.47 & Valid \\
\hline & INN7 & 0.02 & 0.53 & 0.11 & 0.13 & 0.09 & 0.26 & Valid \\
\hline \multirow{8}{*}{ INS } & INS1 & -0.00 & 0.13 & 0.70 & 0.08 & -0.08 & -0.03 & Valid \\
\hline & INS2 & -0.13 & 0.04 & 0.72 & -0.04 & -0.05 & -0.13 & Valid \\
\hline & INS3 & -0.15 & -0.01 & 0.80 & 0.01 & -0.09 & -0.10 & Valid \\
\hline & INS4 & -0.09 & 0.02 & 0.65 & 0.09 & -0.08 & -0.05 & Valid \\
\hline & INS5 & -0.28 & -0.04 & 0.71 & -0.11 & -0.08 & -0.02 & Valid \\
\hline & INS6 & -0.28 & -0.06 & 0.70 & 0.06 & -0.03 & -0.11 & Valid \\
\hline & INS7 & -0.11 & 0.02 & 0.67 & 0.11 & -0.09 & -0.08 & Valid \\
\hline & INS9 & -0.27 & -0.12 & 0.72 & -0.12 & -0.11 & -0.10 & Valid \\
\hline \multirow{5}{*}{ DIS } & DIS2 & 0.20 & 0.09 & -0.06 & 0.72 & 0.39 & 0.22 & Valid \\
\hline & DIS6 & 0.06 & 0.13 & 0.04 & 0.68 & 0.39 & 0.15 & Valid \\
\hline & DIS7 & 0.19 & 0.10 & 0.01 & 0.70 & 0.31 & 0.28 & Valid \\
\hline & DIS9 & 0.20 & 0.03 & -0.08 & 0.67 & 0.34 & 0.18 & Valid \\
\hline & DIS10 & 0.24 & 0.16 & 0.10 & 0.78 & 0.47 & 0.13 & Valid \\
\hline \multirow{5}{*}{ PU } & USE1 & 0.30 & 0.23 & -0.09 & 0.33 & 0.65 & 0.35 & Valid \\
\hline & USE2 & 0.32 & 0.17 & -0.10 & 0.38 & 0.78 & 0.30 & Valid \\
\hline & USE3 & 0.34 & 0.28 & -0.09 & 0.40 & 0.87 & 0.51 & Valid \\
\hline & USE4 & 0.37 & 0.26 & -0.18 & 0.41 & 0.83 & 0.52 & Valid \\
\hline & USE5 & 0.30 & 0.18 & -0.09 & 0.35 & 0.85 & 0.53 & Valid \\
\hline
\end{tabular}




\begin{tabular}{|c|c|c|c|c|c|c|c|c|}
\hline & USE6 & 0.13 & 0.19 & 0.03 & 0.63 & 0.76 & 0.45 & Valid \\
\hline \multirow{6}{*}{ PEU } & EASE1 & 0.12 & 0.32 & -0.14 & 0.20 & 0.46 & 0.81 & Valid \\
\hline & EASE2 & 0.23 & 0.42 & 0.01 & 0.20 & 0.48 & 0.77 & Valid \\
\hline & EASE3 & 0.28 & 0.26 & -0.18 & 0.32 & 0.48 & 0.75 & Valid \\
\hline & EASE4 & 0.06 & 0.25 & 0.05 & 0.13 & 0.32 & 0.61 & Valid \\
\hline & EASE5 & 0.31 & 0.41 & -0.09 & 0.21 & 0.40 & 0.70 & Valid \\
\hline & EASE6 & 0.25 & 0.34 & -0.15 & 0.12 & 0.36 & 0.76 & Valid \\
\hline
\end{tabular}

\section{Average varience extanced (AVE)}

Pengujian Tabel 3 ini dilakukan untuk mengukur banyaknya jumlah varian yang ditangkap oleh konstruknya, dengan perbandingan variansi yang timbul oleh kesalahan yang ada dalam pengukuran [7]. Serta menentukan sebuah data sudah reliabel atau belum, sehingga bisa dikatakan data itu reliabel jika memiliki nilai Average varience extanced (AVE) yang didapatkan minimal 0,5. Adapun hasil dari penelitian ini semua variabel dinilai reliabel.

Tabel 3. Hasil Pengujian (AVE)

\begin{tabular}{ccc}
\hline Variabel & AVE & Keterangan \\
\hline Optimism & 0.52 & Reliabel \\
Innovativeness & 0.51 & Reliabel \\
Insecurity & 0.51 & Reliabel \\
Disscomfort & 0.51 & Reliabel \\
PU & 0.63 & Reliabel \\
PEU & 0.54 & Reliabel \\
\hline
\end{tabular}

4. Reliabilitas konstruk (construct reliability)

Dalam pengujian ini dilakukan dengan 2 tahapan uji, seperti pada Gmabar 2 dan Gambar 3. Di mana dua kriteria pengujiannya adalah Composite Reliability dan Cronbach alpha. Composite Reliability sendiri merupakan pengujiaan reliabilitas yang berfungsi untuk menunjukkan akurasi, konsistensi dari ketepatan suatu alat ukur dalam melakukan pengukuran. Serta mengukur dari blok indikator yang mengukur konstruk. Konstruk dinyatakan reliabel jika nilai Composite Reliability $>0.70$ dan batasan pada skor Cronbach alpha $>0.60$ [8].

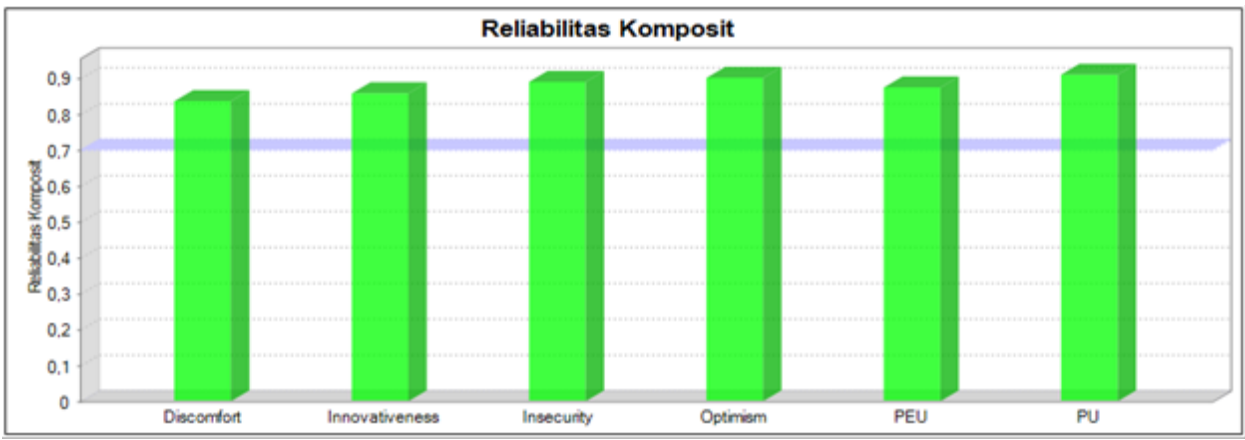

Gambar 2. Composite Reliability

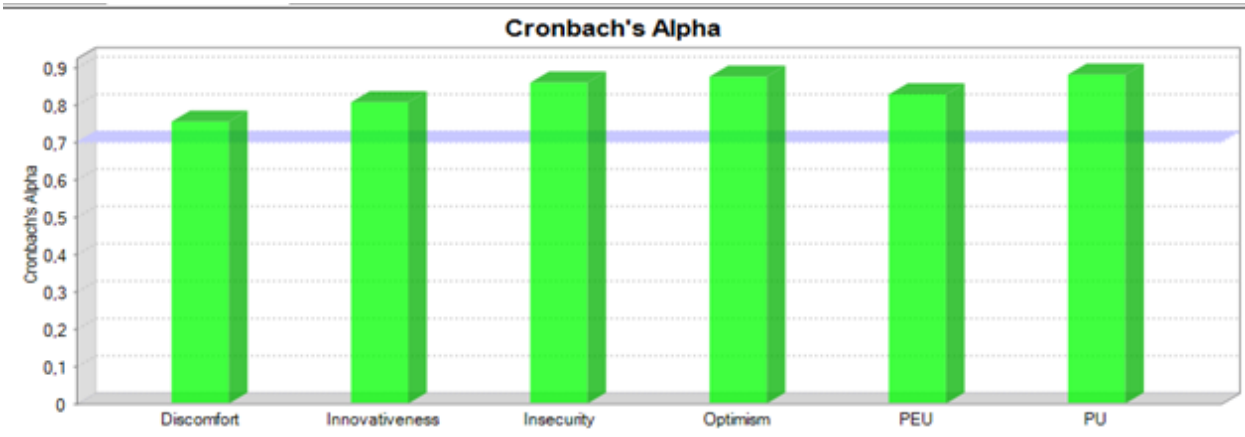

Gambar 3. Cronbach Alpha 


\subsection{Inner Model (structural model)}

Dalam penganalisisan Inner Model dilakukan dalam enam tahapan pengujian yakni $P$ ath Coeficient, Coeficient of Determination, T- test, Effect size, Predictive relevance. Di mana penjelasan dari tiap tahapan akan dijabarkan di bawah ini:

1. Path Coeficient ( $\beta$ )

Pada pengujian Path Coeficient Tabel 4ini dilakukan untuk melihat korelasi antar variabel di mana pengujian dilakukan dengan melihat nilai ambang batasnya harus di atas 0,1 . Di mana memiliki Arti bahwa bahwa jalur atau path yang dimaksud mempunyai pengaruh terhadap model. hasil pengujian path yang tida Tidak Berpengaruh Signifikan yakni pada path PEU->PU yang bernilai 0.00 dan Innovativeness->PEU yang bernilai 0.00 , Disscomfort $->$ PU dan sedangkan sisanya berpengaruh secara signifikan.

Tabel 4. Hasil Pengujian Path Coeficient

\begin{tabular}{ccc}
\hline Relasi Jalur & $B$ & Keterangan \\
\hline PEU->PU & 0.00 & Tidak Berpengaruh Signifikan \\
Discomfort -> PEU & 0.17 & Berpengaruh Signifikan \\
Disscomfort -> PU & 0.00 & Tidak Berpengaruh Signifikan \\
Innovativeness->PEU & 0.00 & Tidak Berpengaruh Signifikan \\
Innovativeness -> PU & 0.86 & Berpengaruh Signifikan \\
Insecurity -> PEU & 0.63 & Berpengaruh Signifikan \\
Insecurity-> PU & 0.77 & Berpengaruh Signifikan \\
Optimism -> PEU & 0.19 & Berpengaruh Signifikan \\
Optimism -> PU & 0.10 & Berpengaruh Signifikan \\
\hline
\end{tabular}

\section{Coeffiency Determinan $\left(\mathrm{R}^{2}\right)$}

Pada pengujian Coeficient of Determination Tabel 5 ini dilakukan untuk melihat persentase tiap variance tiap target endogenous variabel (variabel yang dianggap dipengaruhi oleh variabel lain dalam model). Nilai uji $\mathrm{R}^{2}$ dikatakan kuat jika bernilai 0.67 dikatakan moderat jika bernilai 0.33 dan dikatakan lemah jika bernilai 0.19. Hasil uji Coeffiency Determinan $\left(R^{2}\right)$ di mana nilai dari variabel PEU sebesar 0.30 dikatakan lemah sedangkan pada PU bernilai 0.50 dimana nilai tersebut termasuk ke dalam kategori moderat.

Tabel 5. Hasil Pengujian Coeficient of Determination

\begin{tabular}{ccc}
\hline Variabel & $\mathrm{R}^{2}$ & Keterangan \\
\hline $\mathrm{PEU}$ & 0.30 & Lemah \\
\hline $\mathrm{PU}$ & 0.50 & Moderat \\
\hline
\end{tabular}

\section{T-test}

Dalam t-test digunakan untuk mencari kebenaran dalam hipotesa yang dilakukan sebelumnya pada penelitian ini t-test dicari dengan menggunakan metode bootstrapping pada aplikasi SMARTPLS, dengan menggunakan rumus untuk menentukan nilai ambang T-test. Di mana Persamaan 1 yang digunakan adalah sebagai berikut.

$$
D f=n-k
$$

Ketarangan:

Df: Degree of Freedom n: Jumlah responden k: Jumlah Variabel

Dalam pengujian Tabel 6 ini menggunakan Df sebesar 94 dengan signifikasi 0.25 , sedangkan pada T-tabel yang terdapat pada lampiran 4 nilai ambang batas diterimanya sebuah hipotesa dengan besar df 94 dengan signifikasi 0.25 adalah 0.67 hasil yang didapatkan pada pengujian T-Test adalah 5 relasi jalur yakni PEU-PU, Optimism $\rightarrow$ PE, Innovativeness->PEU, Discomfort -> PEU, Disscomfort $->$ PU, diterima sedangkan pada relasi jalur Optimism $->$ PU, Innovativeness -> PU, Insecurity -> PEU, Insecurity -> PEU, ditolak karena nilai yang didapatkan kurang dari 0.67 di mana hal tersebut merupakan nilai ambang batas diterimanya hipotesa dalam penelitian ini. 


\begin{tabular}{ccc}
\hline Relasi Jalur & $\mathrm{T}$ & Keterangan \\
\hline PEU-PU & 3.41 & Diterima \\
Optimism -> PEU & 1.92 & Diterima \\
Optimism -> PU & 0.10 & Ditolak \\
Innovativeness->PEU & 4.87 & Diterima \\
Innovativeness -> PU & 0.18 & Ditolak \\
Insecurity -> PEU & 0.48 & Ditolak \\
Insecurity-> PU & 0.29 & Ditolak \\
Discomfort $->$ PEU & 1.38 & Diterima \\
Disscomfort -> PU & 4.26 & Diterima \\
\hline
\end{tabular}

\section{Effect Size $\left(\mathrm{f}^{2}\right)$}

Pada pengujian Effect Size $\left(\mathrm{f}^{2}\right)$ Tabel 7 dipakai untuk memprediksi pengaruh variabel tertentu terhadap variabel lainnya dalam struktur model dengan nilai ambang batas sekitar 0,02 untuk pengaruh kecil, 0,15 untuk menengah, dan 0,35 untuk pengaruh besar [5]. Hasil dari perhitungan Effect Size $\left(\mathrm{f}^{2}\right)$ yang terdapat pada penelitian ini adalah nilai PEU->PU, Disscomfort -> PU, Innovativeness->PEU memiliki pengaruh menengah di mana nilai diatas 0,15 sedangkan sisanya memiliki pengaruh kecil

Tabel 7. Hasil Pengujian Effect Size

\begin{tabular}{ccc}
\hline Relasi Jalur & $\mathrm{f}^{2}$ & Keterangan \\
\hline PEU->PU & 0.23 & Menengah \\
Discomfort -> PEU & 0.04 & Kecil \\
Disscomfort -> PU & 0.26 & Menengah \\
Innovativeness->PEU & 0.25 & Menengah \\
Innovativeness -> PU & 0.00 & Kecil \\
Insecurity -> PEU & 0.01 & Kecil \\
Insecurity-> PU & 0.00 & Kecil \\
Optimism -> PEU & 0.05 & Besar \\
Optimism -> PU & 0.03 & Kecil \\
\hline
\end{tabular}

\section{Predictive Relevence}

Pengujian Tabel 8 dilakukan dengan cara blindfonding dan juga digunakan untuk mengukur seberapa baik nilai observasi yang dihasilkan oleh model dan juga estimasi parameternya. Dalam pengujian ini jika nilai Q2 lebih besar dari pada 0 maka menunjukkan nilai yang predictive relevance, sebaliknya jika nilau kurang dari 0 menunjukan model tidak meiliki nilai predictive relevance [5]. Hasil dalam penelitian ini 2 variabel PU dan PEU di mana kedua variabel dinyatakan Relevance karena nilai Q2 diatas 0, sehingga keduanya bisa digunakan dalam penelitian.

Tabel 8. Hasil Pengujian Predictive Relevance

\begin{tabular}{ccc}
\hline Variabel & Q2 & Keterangan \\
\hline PEU & 0.13 & Relevance \\
PU & 0.28 & Relevance \\
\hline
\end{tabular}

\section{Relative Impact $\left(\mathrm{q}^{2}\right)$}

Menggunakan metode blindfonding untuk mengukur relatif pengaruh dari sebuah keterkaitan prediktif suatu variabel tertentu dengan variabel lainnya. Dalam Tabel 9 uji nilai ambang batas sebanyak 0,02 untuk pengaruh yang termasuk kecil, sedangkan nilai 0,15 untuk pengaruh sedang, dan 0,35 untuk pengaruh besar (Hair et al., 2012) adapun Persamaan 2 dalam pengujian ini.

$$
q^{2}=\frac{Q^{2} \text { include }-Q^{2} \text { exclude }}{1-Q^{2} \text { include }}
$$


Tabel 9. Hasil Pengujian Relative Impact

\begin{tabular}{ccccc}
\hline Jalur & $\mathrm{Q}^{2}$ include & $\mathrm{Q}^{2}$ exclude & $\mathrm{q}^{2}$ & Keterangan \\
\hline OPT->PEU & 0.13 & 0.11 & 0.02 & Pengaruh Kecil \\
OPT->PU & 0.28 & 0.27 & 0.01 & Pengaruh Kecil \\
INN->PEU & 0.13 & 0.06 & 0.08 & Pengaruh Kecil \\
INN->PU & 0.28 & 0.28 & 0.00 & Pengaruh Kecil \\
INS->PEU & 0.13 & 0.13 & 0.00 & Pengaruh Kecil \\
INS->PU & 0.28 & 0.28 & 0.00 & Pengaruh Kecil \\
DIS->PEU & 0.13 & 0.12 & 0.01 & Pengaruh Kecil \\
DIS->PU & 0.28 & 0.21 & 0.08 & Pengaruh Kecil \\
PEU->PU & 0.28 & 0.21 & 0.08 & Pengaruh Kecil \\
\hline
\end{tabular}

\section{Kesimpulan}

Adapun kesimpulan yang didapatkan dalam penelitian ini adalah Dilakukan penghapusan indikator yang pada awalnya berjumlah 48 menjadi 40 dikarenakan nilai loading faktor kurang dari 0,5. Adapun indikator yang dihapus adalah OPT7, INN1, INS8, DIS1, DIS3, DIS4, DIS5, DIS6, DIS8. Serta ditolaknya 4 hipotesa dari 9 hipotesa yang ada, yakni OPT->PU, INN->PU, INS-> PEU, dan INS->PU, adapun perbedaan hasil pada temuan penelitian dikarenakan efek dari beberapa faktor diantaranya perbedaan adanya perbedaan objek, hingga jumlah sampel. Sedangkan hipotesa yang diterima terdapat5 hipotesa yakni OPT->PEU, INN$>$ PEU, DIS-> PU, DIS-> PEU dan PEU->PU hal tersebut menunjukkan bahwa optimism, innovativeness tidak mempengaruhi Perceive of Usefullness secara langsung, karena meskipun pada variabel OPT dan INN tidak terpengaruh terhadap PU akan tetapi variabel PEU memiliki pengaruh terahadap PU, sedangkan OPT dan INN memiliki pengaruh pada PEU, oleh karena itu disebut tidak mempengaruhi secara langsung. Sehingga dapat dilihat bahwa dalam lingkup SIMTEKNIK terdapat beberapa pengaruh yang terjadi antara kesiapan dan penerimaan pengguna terhadap penerapan SIMTEKNIK adalah sebagai yaitu sebagai berikut:

1. Pandangan optimisme (optimism) pada pengguna SIMTEKNIK berpengaruh positif terhadap penilaian kemudahan penggunaan SIMTEKNIK. Artinya jika optimisme pengguna SIMTEKNIK tinggi maka hal tersebut akan berpengaruh secara positif terhadap penerimaan pengguna, sehingga menjadi faktor pendorong penerapan penggunaan SIMTEKNIK.

2. Pandangan inovatif (Innovativeness) pengguna SIMTEKNIK memiliki pengaruh positif terhadap penilaian kemudahan penggunaan SIMTEKNIK. Artinya jika tingkat invatif operator SIMTEKNIK tinggi maka hal tersebut akan berpengaruh positif terhadap penerimaan pengguna, sehingga akan menjadi faktor pendorong penerapan SIMTEKNIK.

3. Pandangan ketidaknyamanan (discomfort) pengguna SIMTEKNIK berpengaruh negatif terhadap penilaian kemudahan penggunaan SIMTEKNIK. Artinya jika ketidaknyamanan pengguna SIMTEKNIK tinggi maka hal tersebut akan berpengaruh negatif terhadap penerimaan pengguna, sehingga hal tersebut bisa menjadi menjadi faktor penghambat penerapan SIMTEKNIK.

4. Pandangan ketidaknyamanan (discomfort) pengguna SIMTEKNIK berpengaruh negatif terhadap penilaian kemanfaatan pengguna SIMTEKNIK. Artinya jika ketidaknyamanan pengguna SIMTEKNIK rendah maka akan berpengaruh positif terhadap penerimaan pengguna, sehingga akan menjadi faktor pendorong penerapan SIMTEKNIK berbanding terbalik jika tingkat ketidaknyamanan pengguna SIMTEKNIK tinggi maka hal tersebut akan berpengaruh negatif terhadap penerimaan pengguna, sehingga akan menjadi faktor penghambat untuk penerapan SIMTEKNIK.

5. Penilaian kemudahan (PEU) pengguna SIMTEKNIK berpengaruh positif terhadap penilaian kemanfaatan penggunaan SIMTEKNIK. Berarti jika penilaian kemudahan pada SIMTEKNIK bernilai tinggi maka penilaian kemudahan Operator SIMTEKNIK juga tinggi. hal tersebut akan berpengaruh positif terhadap penerimaan pengguna, sehingga akan menjadi faktor pendorong penerapan SIMTEKNIK,

6. Nilai T-Table tertinggi terdapat pada $\mathrm{Hi}$ (DIS->PEU) sebesar 4.26 dan terendah pada $\mathrm{H} 2$ yaitu 0.10 (OPT->PU).

7. Rata-rata tingkat rasa Inovatif SIMTEKNIK adalah menengah sedangkan pada tingkat, optimis, ketidaknyamanan, dan ketidak amanan Operator SIMTEKNIK adalah tinggi, dan juga pada pengujian R-Square pengaruh PEU adalah moderat dan pengaruh PU rendah. 


\section{Referensi}

[1] E. Wulansari, "Perancangan Sistem Informasi Manajemen Tugas Akhir Berbasis Web Jurusan Teknik Sipil Fakultas TeknikUniversitas Tanjungpura."

[2] Rozandy, R. A., Santoso, I., Putri, S. A., Jurusan, A., Industri, T., ... Brawijaya, U. (n.d.). Analisis Variabel - Variabel Yang Mempengaruhi Tingkat Adopsi Teknologi Dengan Metode Partial Least Square (Studi Kasus Pada Sentra Industri Tahu Desa Sendang, Kec. Banyakan, Kediri). 1(3).

[3] K. Osborn and B. L. White, "Analisis Faktor Optimalisasi Golden Age Anak Usia," vol. 4, no. 1, pp. 48-56, 2018.

[4] A. S. Hussein, "Penelitian Bisnis dan Menejemen Menggunakan Partial Least Sqares (PLS) dengan smartPLS 3.0," Clinical Orthodonticsand Research, vol. 2, no. 2. pp. 49-52, 2015.

[5] A, Nina Eka 2019. Evaluasi Pengaruh Kesiapan Pengguna Terhadap Penerimaan Dapodik Menggunakan Metode Tram (Technology Readinness Acceptance Model). Skripsi. Malang: Universitas Muhammadiyah Malang.

[6] H. Rosmayanti, H. Aryadita, and A. D. Herlambang, "Analisis Penerimaan Teknologi Cloud Storage Menggunakan Technology Readiness Acceptance Model (TRAM) Pada Badan Eksekutif Mahasiswa Institut Teknologi Sepuluh Nopember", vol. 2, no. 10, pp. 3632_3639, 2018

[7] A. P. Kegunaan, P. Kemudahan, K. T. Informasi, D. A. N. Kerahasiaan, T. Minat, and L. Santioso, "Penggunaan E-Filling," vol. 18, no. 2, 2018.

[8] F. Yusup, "Uji Validitas dan Reliabilitas Instrumen Penelitian Kuantitatif," J. Tarb.J. IIm.Kependidikan, vol. 7, no. 1, pp. 17-23, 2018, doi: 10.18592/tarbiyah.v7i1.2100. 